\title{
С.О. Сокольник
}

\section{ЗАСТОСУВАННЯ АРГОН-ПЛАЗМОВОЇ КОАГУЛЯЦЇ̈ В КОМПЛЕКСНОМУ ЛІКУВАННІ ШЛУНКОВО-КИШКОВИХ КРОВОТЕЧ У ДІТЕЙ, ХВОРИХ НА ВИРАЗКОВУ ХВОРОБУ}

Вищий державний навчальний заклад України «Буковинський державний медичний університет», м. Чернівці

Резюме. Проаналізована ефективність застосування аргон-плазмової коагуляції в комплексному лікуванні шлунково-кишкових кровотеч у 12 дітей, хворих на виразкову хворобу. Первинний стійкий гемостаз досягнуто у 91,7 \% пацієнтів, на 28-му добу загоєння виразкового дефекту відмічено у 100 \% хворих, термін стаці-

Вступ. Виразкова хвороба шлунка та дванадцятипалої кишки (BX) у дітей залишається актуальною проблемою дитячої гастроентерології та дитячої хірургії, оскільки останніми роками спостерігається зростання питомої ваги захворювання та його ускладнень, що потребують оперативного лікування [4]. На жаль, незважаючи на великі досягнення консервативної терапії ВX, нерідко спостерігаються рецидиви захворювання. Крім того, не завжди медикаментозна терапія запобігає виникненню різних ускладнень, які впливають на прогноз перебігу ВХ [6].

Одним із найбільш актуальних та невирішених завдань ургентної хірургії є проблема шлунково-кишкових кровотеч (ШКК), які посідають перше місце серед ускладнень ВХ за частотою виникнення [1].

Попри спонтанний гемостаз, що спостерігається в більшості пацієнтів із ШКК із хронічних виразок, у кожного п'ятого виникає рецидив [5].

Деякі вчені пояснюють виникнення ШКК на тлі консервативної терапії ВX нерівноцінною якістю її впливу на клінічне та морфологічне загоєння виразкового дефекту. Тому важливим та перспективним напрямом лікування ШКК є використання ендоскопічних методів місцевого гемостазу, які є альтернативою хірургічному втручанню, володіють меншою травматизацією м'яких тканин та дозволяють, на думку ряду авторів [2, 3], досягти швидкої зупинки кровотечі та скоротити строки загоєння виразки.

У літературі описується ряд методів ендоскопічного гемостазу, застосування яких дозволяє досягти гарних результатів, однак більшість із них мають недоліки, зокрема - інвазивність, неможливість виконання на тлі активної кровотечі та в анатомічно тяжких місцях локалізації виразкового дефекту [7]. Тому не зменшується інтерес хірургів до пошуку нових патогенетично обгрунтованих методів зупинки ШКК, які б мали високу ефективність та мінімум недоліків.

Мета дослідження. Оцінити ефективність, безпечність та особливості застосування аргонплазмової коагуляції в комплексному лікуванні шлунково-кишкових кровотеч у дітей, хворих на онарного лікування скоротився на $4,8 \pm 2,3$ доби, тримісячне катамнестичне спостереження за хворими не виявило рецидиву кровотечі.

Ключові слова: діти, шлунково-кишкова кровотеча, аргон-плазмова коагуляція, виразкова хвороба.

виразкову хворобу, та визначити покази до іiі застосування.

Матеріал і методи. Проведено аналіз лікування 12 дітей із ШКК, хворих на ВХ, віком 7-18 років (середній вік 13,2 2 ,8 року після підписання інформованої згоди на участь у дослідженнях, ознайомлення з методом лікування та можливими ускладненнями.

Критерії включення дітей у дослідження: ВX, ускладнена ШКК; вік 7-18 років; підписана інформована згода на участь у дослідженнях. Критерії виключення: неускладнена ВХ; вживання антибактеріальних, антисекреторних, нестероїдних та стероїдних засобів упродовж останнього місяця; захворювання крові та судин; участь пацієнтів у інших дослідженнях; наявність хронічної супутньої патології, що може вплинути на можливість проведення запропонованого лікування. Критерії виходу пацієнта $з$ дослідження: рішення пацієнта припинити свою участь у дослідженнях; недотримання пацієнтом рекомендацій лікаря; поява у процесі дослідження критеріїв виключення.

Для об'єктивізації ендоскопічної картини у хворих на ВХ із ШКК використовували класифікацію J. Forrest (1974): F I - кровотеча, що триває; F II - кровотеча, що зупинилась; F III - кровотеча відсутня. Так, серед обстежених було п’ять пацієнтів із кровотечею, що триває, шість із нестабільним гемостазом та один - зі стабільним гемостазом.

При надходженні до стаціонару оцінювали тяжкість крововтрати (рис. 1).

Всім дітям до та після лікування проведено комплекс клінічно-параклінічних досліджень, який включав: бальну оцінку вираженості клінічної симптоматики (візуально-аналогова шкала за 4-бальною системою: 0 - немає ознаки, симптому; 1 - слабко виражена ознака, симптом; 2 помірно виражений симптом; 3 - значно виражений) та час iі редукції, об'єктивне обстеження, загальноклінічні лабораторні методи, коагулограму (за загальноприйнятими методиками), екстрену та контрольну езофагогастродуоденоскопію (ЕФГДС) із візуалізацією джерела кровотечі, оці- 
нкою його за Forrest та оцінкою ефективності проведеного гемостазу, рН-метрію (0,9-1,2 - гіперацидність виражена; 1,3-1,5 - гіперацидність помірна; 1,6-2,2 - нормоацидність; 2,3-3,5 - гіпоацидність помірна; 3,6-6,9 - гіпоацидність виражена; 7 та більше - анацидність), ультразвукове дослідження органів черевної порожнини. Крім того, визначено вміст про- (інтерлейкін- $1 \beta$, інтерлейкін-8) та протизапальних (інтерлейкін-4, рецепторний антагоніст інтерлейкіну-1) інтерлейкінів та монооксиду нітрогену в сироватці крові імуноферментним методом. Наявність гелікобактерної інфекції (НР) визначали напівкількісною оцінкою ступеня засівання НР методом Л.І. Аруїна (1998) та за допомогою твердофазного імуноферментного аналізу за загальноприйнятою методикою 3 використанням діагностичної тест-системи «ГелікоБест-антитіла» (набір реактивів ЗАТ «Вектор БЕСТ» (Російська Федерація)) з визначенням титру антитіл до антигену CagA HP у сироватці крові.

На тлі стандартного медикаментозного лікування проводили ендоскопічний гемостаз з використанням АПК, який уводили через гнучкий ендоскопічний зонд із використанням електрохірургічного апарата «EMED ES 350 argon» (Польща). Можливість спалаху з виникненням електродуги обов'язково попередньо перевірялася за межами ендоскопа, до уведення зондаелектрода в просвіт шлунка чи ДПК. Через зонделектрод до місця кровотечі подавався інертний газ аргон, який витісняв кисень довкола ранового дефекту. Вплив на джерело кровотечі здійснювали серіями коротких (1-3 секунди) експозицій у режимі пульсації. Струмінь аргонової плазми швидко коагулював велику поверхню з утворенням тонкого шару (до 3 мм) надійного струпа. Задля уникнення глибоких некрозів та перфорації стінки шлунка чи ДПК зонд-електрод під час проведення процедури АПК наближували до джерела кровотечі до моменту появи плазми на відстань не ближче 3-10 мм та не допускали прямого контакту його зі стінкою органа. Безконтактність методу усувала ймовірність відриву утвореного струпа після проведеної коагуляції. Контроль за джерелом кровотечі після проведеного ендоскопічного гемостазу здійснювали через 12 , 24 та 72 години. Обробка отриманих даних проводилась за допомогою пакета комп’ютерних програм «Statistica $6.0 »$.

Результати дослідження та їх обговорення. У переважної більшості дітей діагностовано ВX ДПК (75,0 \%), у решти - ВХ шлунка. Аналіз анамнестичних даних показав, що переважна більшість пацієнтів $(66,7$ \%) надійшла до стаціонару на 2-гу добу від появи клінічної симптоматики, оскільки вона не була яскраво вираженою. Дитина, в якої при ЕФГДС діагностовано стабільний гемостаз, звернулася до клініки на третю добу. Хоча в неї не було виражених ознак кровотечі, проте дане ускладнення ВХ відмічено в анамнезі.

Тривалість виразкового анамнезу в пацієнтів була різною, переважно до трьох років $(75,0 \%$, $\varphi=2,56, p<0,01)$. У трьох $(25,0 \%)$ дітей маніфестація ВХ почалась з ускладнення - ШКК. Всі діти, в анамнезі яких діагностовано ВХ, отримували сучасну протокольну противиразкову терапію, однак лише 25,0 \% - протирецидивне лікування. Рецидив ВХ діагностовано в 58,3 \% пацієнтів.

Аналіз клінічної картини виявив наявність у дітей трьох основних синдромів (больового, диспепсичного та астеновегетативного) з різним ступенем вираженості.

Вірогідно частіше ШКК супроводжувалась абдомінальним больовим синдромом (83,3 \%), тоді як у 16,7 \% хворих відмічено безбольовий перебіг захворювання $(\varphi=3,57, p<0,01)$. Причиною звернення за медичною допомогою в останніх була наявність інших проявів ШКК. Аналіз інтенсивності больового синдрому показав, що на виражений біль у животі, який виник гостро,

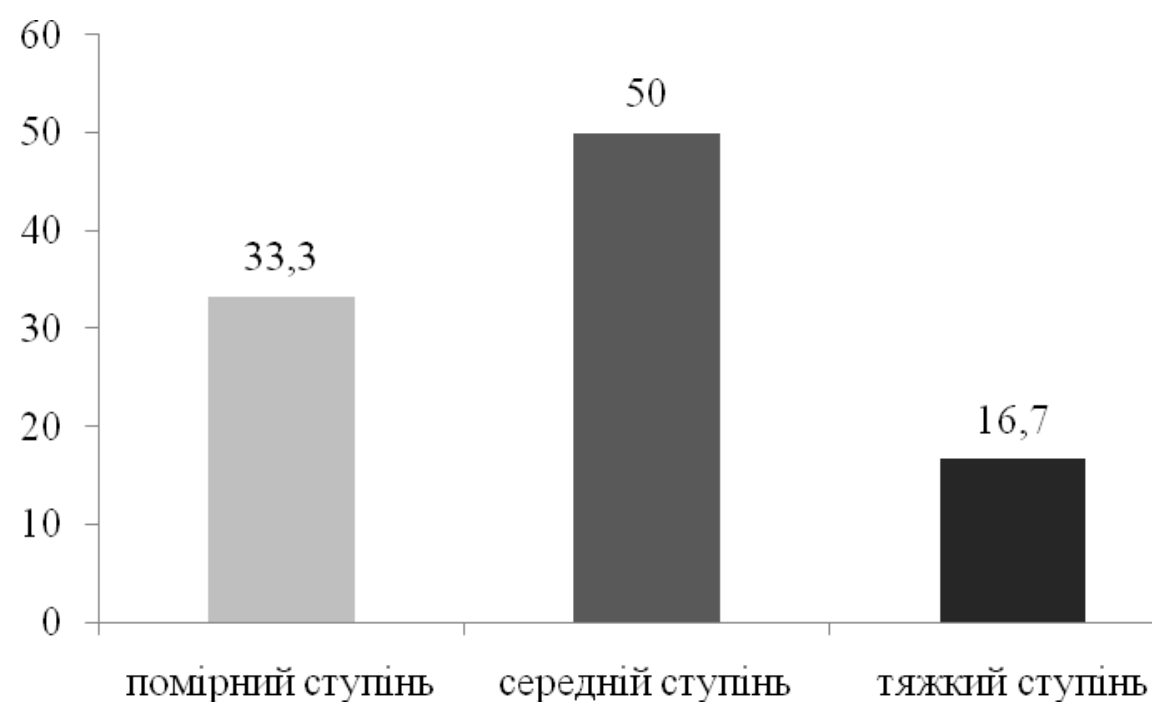

Рис. 1. Розподіл дітей, хворих на ускладнену шлунково-кишковою кровотечею виразкову хворобу, залежно від ступеня крововтрати (\%) 


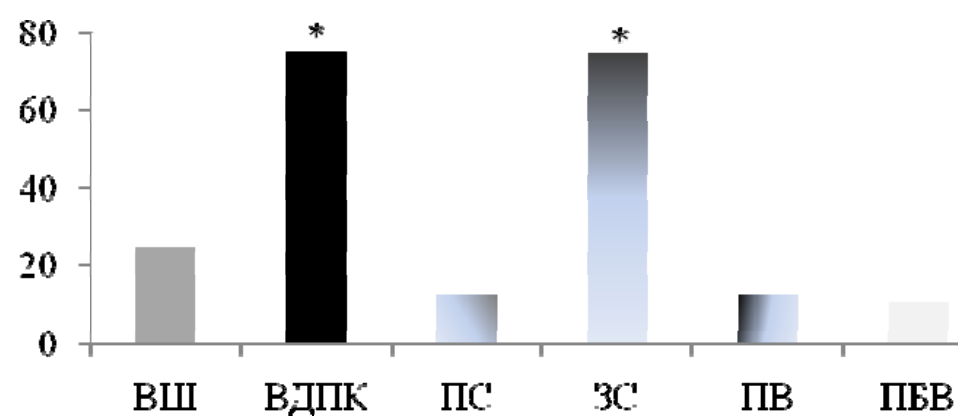

Рис. 2. Топографічне розташування джерела кровотечі (\%)

Примітка. ВШ - виразка шлунка, ВДПК - виразка дванадцятипалої кишки, ПС - передня стінка цибулини дванадцятипалої кишки, ЗС - задня стінка цибулини дванадцятипалої кишки, ПВ - поцілункові виразки, ПБВ - постбульбарний відділ; $р \varphi<0,01$

скаржились в 1,5 раза частіше $(60,0 \%$ випадків), ніж на біль середньої інтенсивності, який відмічали 40,0 \% пацієнтів $(\varphi=0,90, \mathrm{p}>0,05)$.

Найбільш частою локалізацією болю були епігастральна та пілородуоденальна ділянки 3 незначним переважанням останньої $(\varphi=1,01$, $\mathrm{p}>0,05)$, у двох $(16,7 \%$ ) осіб - поєднана локалізація болю. Розлитий біль мав місце теж лише у двох $(16,7 \%)$ пацієнтів.

Скарги на диспепсичні прояви пред'являли $100 \%$ пацієнтів. Так, блювання 3 кров'ю діагностовано в дев'яти (75,0 \%) дітей, чорне дьогтеподібне випорожнення - у шести $(50,0 \%)$ пацієнтів. Десять (83,3 \%) пацієнтів із ШКК скаржилися на виникнення раптової загальної слабкості, двоє (16,7 \%) - на запаморочення.

Враховуючи те, що одним із головних етіологічних факторів розвитку ВХ є гелікобактерна інфекція, всі діти були обстежені на НР. Так, гелікобактеріоз діагностовано у 75,0 \% дітей $(\varphi=2,56, \mathrm{p}<0,01)$.

Екстрена ЕФГДС дозволила виявити джерело кровотечі у 83,3 \% дітей. Проте встановлено (рис. 2), що в трьох (25,0 \%) осіб виразковий дефект локалізувався в препілоричному відділі шлунка, у решти - у ДПК (одна $(8,3 \%$ ) дитина постбульбарний відділ, вісім (66,7 \%) - цибулина ДПК: одна - поцілункові виразки, одна - передня стінка, шість - задня стінка). Аналіз топографічного розташування джерела кровотечі показав, що серед дітей із ШКК, хворих на ВХ, переважає локалізація виразкового дефекту по задній стінці цибулини ДПК $(\varphi=2,97, \mathrm{p}<0,01)$. Це підтверджують і дані інших досліджень щодо ризику виникнення кровотечі за даної локалізації виразки [6].

Попри переважання в групі обстежених виразок середнього розміру, у двох дітей (одна 3 яких $з$ маніфестацією ВХ із ШКК) - великі виразки $(\varphi=3,23, p<0,01)$. Виразок малого розміру в даній групі спостереження не було.

Лише в однієї дитини діагностовано нормоацидність, у решти - гіперацидність $(\varphi=4,83$, $\mathrm{p}<0,01)$, гіпоацидність у обстежених осіб не виявлено. Серед хворих із підвищеною кислотопродукувальною функцією шлунка у 81,1 \% показники pH-метрії свідчили про помірну гіперацидність, проте у двох пацієнтів значення знаходились у інтервалі вираженої гіперацидності $(\varphi=3,23$, $\mathrm{p}<0,01)$. Останні були хлопчики з ВХ шлунка.

Аналіз показників інтерлейкінового гомеостазу в сироватці крові при надходженні встановив значне підвищення в обстежених дітей (порівняно зі стандартизованими нормами відповідно до інструкції) вмісту прозапальних інтерлейкінів (середні значення інтерлейкіну- $1 \beta=$ $92,3 \pm 7,2$ пг/мл, інтерлейкіну-8 = 102,6 $\pm 8,4$ пг/мл) на тлі незначного підвищення протизапальних інтерлейкінів (середні значення інтерлейкіну-4 = $15,4 \pm 2,6$ пг/мл, рецепторного антагоніста інтерлейкіну-1 $=1015 \pm 48,4$ пг/мл). Виражені зміни цитокінового балансу підтверджують патогенетичну роль прозапальних інтерлейкінів у механізмі розвитку запалення та виникнення ШКК.

Проведено аналіз концентрації моноксиду нітрогену, як одного з медіаторів неспецифічного захисту слизової оболонки шлунка, у сироватці крові осіб із ШКК. У всіх обстежених відмічено високі показники концентрації моноксиду нітрогену при надходженні до стаціонару (середне значення - 22,54 $\pm 0,07$ мкмоль/л).

Первинний ендоскопічний гемостаз досягнуто у всіх обстежених із кровотечами F I, F II (дитині зі стабільним гемостазом, в анамнезі якої була кровотеча, з метою профілактики рецидиву теж проведено АПК). При повторній ЕФГДС діагностовано стійкий гемостаз у 91,7 \% пацієнтів. Одній дитині 3 нестійким первинним гемостазом проведено повторний сеанс АПК.

Аналіз клінічної картини показав редукцію

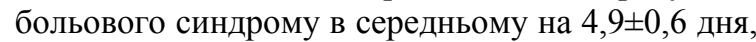
диспепсичного - на 3,3 $\pm 0,4$ дня, інтоксикаційно-

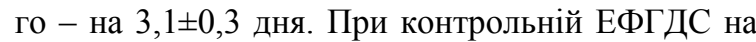
28-му добу у всіх дітей спостерігали загоєння виразкового дефекту.

Слід також зазначити, що на 14-ту добу в більшості пацієнтів спостерігали зниження концентрації прозапальних інтрелейкінів і зростання вмісту протизапальних інтерлейкінів та зниження концентрації монооксиду нітрогену в сироватці крові. Проте у трьох $(25,0$ \%) пацієнтів діагностовано збереження високої концентрації прозапальних інтерлейкінів та монооксиду нітрогену у фазі 
рубцювання виразки. Це були хлопчики з тяжкою та середнього ступеня крововтратою. Дані зміни можна оцінювати як прогностично несприятливі до ризику виникнення рецидиву кровотечі, що потребує підбору індивідуалізованої лікувальнопрофілактичної тактики.

Тривалість перебування в хірургічному стаціонарі коливалась від чотирьох до восьми днів та в середньому склала 5,5 $\pm 0,4$ дня, після чого діти були переведені до гастроентерологічного відділення для продовження противиразкової терапії.

Термін стаціонарного лікування дітей, хворих на ВХ, ускладнену ШКК, при включенні до лікування АПК у цілому зменшився на 4,8 2,3 доби.

Катамнестичне спостереження впродовж трьох місяців не виявило виникнення рецидиву кровотечі в обстежених дітей.

\section{Висновок}

Проведені дослідження показали необхідність включення аргон-плазмової коагуляції до медикаментозної терапії в дітей із шлунковокишковими кровотечами. Застосування аргонплазмової коагуляції при ендоскопічному гемостазі у хворих на виразкову хворобу із кровотечами дозволяє добитися стійкого гемостазу та зменшити відсоток рецидивів кровотечі. Безконтактність методу підвищує безпечність процедури та знижує ймовірність виникнення ускладнень. Показами для використання аргон-плазмової коагуляції є наявність активної кровотечі та нестабільного гемостазу.
Перспективи подальших досліджень. Необхідно розробити алгоритм комплексного диференційованого підходу до лікування шлунковокишкових кровотеч у дітей, хворих на виразкову хворобу, залежно від стигми кровотечі, ступеня крововтрати та локалізації виразкового дефекту.

\section{Література}

1. Запруднов А.М. Желудочно-кишечные кровотечения у детей: монография / А.М. Запруднов, К.И. Григорьев, А.Ф. Дронов. - М.: Медицина, 1998. - 207 с.

2. Избицкий В.В. Комплексное эндоскопическое лечение острых желудочно-кишечных кровотечений язвенной этиологии / В.В. Избицкий, С.Н. Гулевский // Запорож. мед. ж. - 2013. - № 3 (78). - С. 25-27.

3. Удосконалені алгоритми діагностики та лікування гострої шлунково-кишкової кровотечі: Методичні рекомендації / П.Д. Фомін, Я.С. Березницький, В.В. Бойко [та ін.]; Укрмедпатентінформ МОЗ України. - К.: Б.в, 2012. -108 с.

4. Цвєткова Л.Н. Язвенная болезнь желудка и двенадцатиперстной кишки у детей. Национальное руководство «Педиатрия» / Л.Н. Цветкова, И.Ю. Мельникова, С.В. Бельмер - М.: ГЭОТАР-Медиа, 2009. C. $723-732$.

5. International consensus recommendations on the management of patients with nonvariceal upper gastrointestinal bleeding [Guideline] / A.N. Barkun, M. Bardou, E.J. Kuipers [et al.] // Ann. Intern. Med. - 2010. - Vol. 152 (2). P. 101-113.

6. Laine L. Management of patients with ulcer bleeding / L. Laine, D.M. Jensen // Am. J. Gastroenterol. - 2012. Vol. 107 (3). - P. 345-360.

7. The role of endoscopy in the management of acute nonvariceal upper GI bleeding [Guideline ASGE] / J.H. Hwang, D.A. Fisher, T. Ben-Menachem [et al.] // Gastrointestinal. Endoscopy. - 2012. - Vol. 75 (6). - P. 1132-1138.

\section{ИСПОЛЬЗОВАНИЕ АРГОН-ПЛАЗМЕННОЙ КОАГУЛЯЦИИ В КОМПЛЕКСНОМ ЛЕЧЕНИИ ЖЕЛУДОЧНО-КИШЕЧНЫХ КРОВОТЕЧЕНИЙ У ДЕТЕЙ С ЯЗВЕННОЙ БОЛЕЗНЬЮ}

\section{С.А. Сокольник}

Резюме. Проанализирована эффективность использования аргон-плазменной коагуляции в комплексном лечении желудочно-кишечных кровотечений у 12 детей с язвенной болезнью. Первичный стойкий гемостаз достигнут у 91,7 \% пациентов, на 28-ые сутки заживление язвенного дефекта виявлено у 100 \% больных, сроки стационарного лечения сократились на 4,8 2,3 сутки, трехмесячное катамнестическое наблюдение за больными не обнаружило рецидива кровотечения.

Ключевые слова: дети, желудочно-кишечное кровотечение, аргон-плазменная коагуляция, язвенная болезнь.

\section{ARGON PLASMA COAGULATION USING IN TREATMENT OF GASTROINTESTINAL BLEEDING IN CHILDREN WITH PEPTIC ULCER}

\section{S.O. Sokolnyk}

Abstract. Efficiency of argon plasma coagulation use in treatment of gastrointestinal bleeding in 12 children with peptic ulcer has been analyzed. Primary consistent hemostasis was achieved in $91,7 \%$ of patients, on the $28^{\text {th }}$ day healing of the ulcer was observed in $100 \%$ of patients, the term of in-patient treatment was reduced to $4,8 \pm 2,3$ days, a three-month follow-up observation of the children showed no rebleeding.

Key words: children, gastrointestinal bleeding, argon plasma coagulation, peptic ulcer.

Higher State Educational Institution of Ukraine "Bukovinian State Medical University" (Chernivtsi) 